OPEN ACCESS

Edited by:

Aristide Maggiolino,

University of Bari Aldo Moro, Italy

Reviewed by:

Mirian Pateiro,

Centro Tecnológico de la Carne, Spain Antonio Natalello,

University of Catania, Italy

*Correspondence: Xiangfeng Kong nnkxf@isa.ac.cn

Specialty section:

This article was submitted to Nutrition and Metabolism

a section of the journal

Frontiers in Nutrition

Received: 28 July 2021 Accepted: 05 October 2021 Published: 05 November 2021

Citation:

Cai $Q$, Hu C, Tang W, Jiang $H$, Geng M, Huang X and Kong X (2021) Dietary Addition With Clostridium butyricum and Xylo-Oligosaccharides Improves Carcass Trait and Meat Quality of Huanjiang Mini-Pigs. Front. Nutr. 8:748647. doi: 10.3389/fnut.2021.748647

\section{Dietary Addition With Clostridium butyricum and Xylo-Oligosaccharides Improves Carcass Trait and Meat Quality of Huanjiang Mini-Pigs}

\author{
Qiaoli Cai ${ }^{1,2}$, Chengjun Hu ${ }^{1,3}$, Wu Tang ${ }^{1}$, Huijiao Jiang ${ }^{1,2}$, Meimei Geng ${ }^{1}$, Xingguo Huang ${ }^{2}$ \\ and Xiangfeng Kong ${ }^{1,2 *}$ \\ ${ }^{1}$ Hunan Provincial Key Laboratory of Animal Nutrition Physiology and Metabolism Process, Institute of Subtropical \\ Agriculture, Chinese Academy of Sciences, Changsha, China, ${ }^{2}$ College of Animal Science and Technology, Hunan \\ Co-Innovation Center of Animal Production Safety, Hunan Agricultural University, Changsha, China, ${ }^{3}$ Tropical Crops Genetic \\ Resources Institute, Chinese Academy of Tropical Agricultural Sciences, Haikou, China
}

This study was conducted to investigate the effects of dietary addition with Clostridium butyricum (CB) and xylo-oligosaccharides (XOS) on growth performance, carcass trait, and meat quality of pigs. A total of 128 Huanjiang mini-pigs with an initial body weight of $9.5 \pm 0.1 \mathrm{~kg}$ were randomly assigned to one of four groups. The pigs in control (Con) group were fed a basal diet and those in the experimental groups were fed the basal diet supplemented with $0.05 \%$ CB (CB group), 0.02\% XOS (XOS group), or $0.05 \%$ CB $+0.02 \%$ XOS (CB + XOS group). Eight replicate pens were used per group with four pigs per pen. On days 28,56 , and 84 of the trial, the growth performance, carcass trait, and meat quality were evaluated. The results showed that dietary CB addition decreased $(p<0.05)$ the average daily gain and increased $(p<0.05)$ the ratio of feed intake to body weight gain at day 28 of the trial; $\mathrm{CB}, \mathrm{XOS}$, and $\mathrm{CB}+\mathrm{XOS}$ addition increased $(p<0.05)$ the backfat thickness at day 84 of the trial compared with the Con group. Dietary $\mathrm{CB}, \mathrm{XOS}$, and $\mathrm{CB}+\mathrm{XOS}$ addition increased $(p<0.05)$ the $\mathrm{pH}_{45 \mathrm{~min}}$, while decreased $(p<0.05)$ the marbling score at day 28 of the trial compared with the Con group. Dietary CB + XOS addition increased $(p<0.05)$ the contents of Ala, Arg, Asp, Gly, His, Leu, Lys, Met, Phe, Ser, Thr, Tyr, and Val in muscle at day 56 of the trial. At day 84 of the trial, dietary $C B$ addition increased the contents of nonessential amino acid (NEAA), total amino acid (TAA), and monounsaturated fatty acid (MUFA), while decreased $(p<0.05)$ the percentage of C20:1 in muscle compared with the Con group. Collectively, dietary addition with $0.05 \%$ CB and $0.02 \%$ XOS could not alter the growth performance, but increase carcass trait, meat quality, and muscular nutrient contents in Huanjiang mini-pigs.

Keywords: carcass trait, Clostridium butyricum, growth performance, Huanjiang mini-pigs, meat quality, xylooligosaccharides 


\section{INTRODUCTION}

The pork is one of the most important animal-derived foods for human consumption. However, less skeletal muscle yield is one of the major problems in swine production (1). Consumers increasingly focus on the relationship between nutrition and health and show a preference for high-quality meat products (2). Consequently, improving the meat yield and quality has naturally become a hot issue in animal nutrition research. Meat quality can be improved by nutrition strategy (3). Therefore, developing a novel feed strategy is an urgent necessary for swine production.

Previous study showed that there is a potential link between the gut microbes and body fat deposition in animals (4). For instance, microbiota transplants from obese mice induced obesity in germ-free mice (5). In addition, intestinal microbes present important impacts on the physiological activities and health of the host (6). Therefore, modulation of gut microflora might be a feasible mean to improve meat quality. Recently, Clostridium butyricum (CB) and xylo-oligosaccharides (XOS) have attracted growing interest. Dietary addition with these additives could provide nutrients for probiotic Bifidobacteria and Lactobacilli and preferentially stimulate the growth or activity of indigenous bacteria in the gut, thus maintaining intestinal microflora balance and promoting animal growth $(7,8)$. In addition, dietary $\mathrm{CB}$ could produce short-chain fatty acids (SCFAs) (9) and XOS could be utilized by the bacteria to produce SCFAs (10). The SCFAs play a vital role in maintaining gut integrity and regulating glucose homeostasis, lipid metabolism, appetite, and immune function (11). Therefore, the CB and XO as effective feed additives have been widely used in swine production. However, the interactive effects of these additives on the growth performance, carcass trait, and meat quality of pigs are still unclear.

Huanjiang mini-pig is a local miniature pig breed and is well known for its high-quality meat. The slaughter weight required by the different consumption methods is different. For example, roast pork generally selects $7.5-10 \mathrm{~kg}$ of mini-pigs, while processing bacon requires a larger body weight of minipigs. However, this breed is mainly fed with corn, wheat bran, rice bran, and low-quality green roughage (12), which are unfavorable to the growth potential and meat quality of mini-pigs. Therefore, the development of effective feed additives is of great significance for improving their meat quality. We hypothesized that dietary addition with both $\mathrm{CB}$ and XOS may synergistically improve the growth performance and meat quality of pigs. This study was conducted to test this hypothesis by determining growth performance, carcass trait, and meat quality of Huanjiang minipigs with different body weights (ages) after dietary CB and XOS addition and provided a novel nutrition intervention strategy for meat quality improvement.

\section{MATERIALS AND METHODS}

\section{Animals, Diets, and Treatments}

A total of 128 Huanjiang mini-pigs with an initial body weight (BW) of $9.5 \pm 0.05 \mathrm{~kg}$ were randomly assigned into one of four groups. Each group consisted of eight replicate pens with four pigs per pen (male: female $=1: 1$ ). The pigs in Con group
TABLE 1 | Compositions and nutrient levels of basal diets (air-dry basis) (\%).

\begin{tabular}{lcc}
\hline Ingredients & $\begin{array}{c}\text { Prophase } \\
\text { nursery diet }\end{array}$ & $\begin{array}{c}\text { Anaphase } \\
\text { nursery diet }\end{array}$ \\
\hline Corn & 55.00 & 58.00 \\
Soybean meal & 22.00 & 17.65 \\
Wheat bran & 10.63 & 12.05 \\
Rice bran & 8.37 & 8.30 \\
Premix & & 4.00 \\
Total & 4.00 & 100.00 \\
Nutrient levels & & \\
Digestible energy (MJ/kg) & 100.00 & 13.38 \\
Crude protein & 13.48 & 14.70 \\
Crude fiber & 16.13 & 14.96 \\
Calcium & 14.67 & 0.69 \\
Phosphorus & 0.70 & 0.38 \\
Lysine & 0.38 & 0.78 \\
Methionine + Cysteine & 0.88 & 0.47 \\
Threonine & 0.50 & 0.46 \\
\hline
\end{tabular}

${ }^{a}$ Premix provided the following for per kilogram of the diet: Vitamin A 4,000 IU, Vitamin D3 1,200 IU, Vitamin E $40 \mathrm{IU}$, Vitamin K3 0.8 mg, Vitamin B1 1.6 mg, Vitamin B2 1.6 mg, Vitamin B6 $1.2 \mathrm{mg}$, Vitamin B12 $16 \mu \mathrm{g}$, biotin $0.08 \mathrm{mg}$, pantothenic acid 6 mg, niacin $14 \mathrm{mg}$, choline chloride $300 \mathrm{mg}$, Cu $127 \mathrm{mg}$, Fe 171.6mg, Zn $116 \mathrm{mg}, \mathrm{Mn} 43 \mathrm{mg}, \mathrm{K}$ $0.34 \mathrm{mg}$, I $0.26 \mathrm{mg}$, Co $0.14 \mathrm{mg}$, and Se $0.16 \mathrm{mg}$.

${ }^{b}$ Nutrient levels were calculated values.

were fed a basal diet and those in the experimental groups were fed the basal diet supplemented with $0.05 \% \mathrm{CB}$ (CB group), $0.02 \%$ XOS (XOS group), or $0.05 \% \mathrm{CB}+0.02 \%$ XOS $(\mathrm{CB}+$ $\mathrm{XOS}$ group). A corn and soybean meal-based diet refers to the recommendations of the Chinese National Feeding Standard for Swine (2004) and premix refers to the National Research Council (NRC) recommended requirements (2012) for growingfinishing pigs (Table 1). The CB was provided by the Shandong Baolai-Leelai Bio-Industrial Corporation, Ltd., Taiwan, China and contains $\geq 1 \times 10^{9}$ colony-forming unit (CFU) of viable $\mathrm{CB}$ per gram; the XOS was provided by the Shandong Longlive BioTechnology Corporation, Ltd., Dezhou, China and the content of main components (including xylose, xylotriose, and xylotetraose) is $\geq 35 \%$. The doses of $\mathrm{CB}$ and XOS in the diets were 0.05 and $0.02 \%$, respectively.

After 3-day adaptation period, the pigs were housed in pens and had free access to their diets and water. The feeding trial lasted for 84 days and the animals were fed a prophase nursery diet (from 1 to 56 days) or an anaphase nursery diet (from 57 to 84 days).

\section{Growth Performance Determination}

The BW of pigs was weighed at the beginning and the termination of the trial for calculating average daily gain (ADG). Feed intake was weighed daily to calculate the average daily feed intake (ADFI). The feed efficiency was determined by using the $\mathrm{F}: \mathrm{G}$ ratio based on the feed intake and BW.

\section{Sample Collection}

On days 28, 56, and 84 of the feeding trials, pigs (eight pigs per treatment with one pig per pen) with average $\mathrm{BW}$ 
TABLE 2 | Effects of dietary addition with Clostridium butyricum (CB) and xylo-oligosaccharides (XOS) on growth performance of Huanjiang mini-pigs.

\begin{tabular}{|c|c|c|c|c|c|c|}
\hline Items & Con group & CB group & XOS group & CB + XOS group & SEM & $p$ value \\
\hline Initial BW, kg & 9.49 & 9.49 & 9.49 & 9.49 & 0.045 & 0.84 \\
\hline Finial BW, kg & 36.91 & 36.39 & 37.40 & 37.23 & 0.500 & 0.76 \\
\hline \multicolumn{7}{|l|}{ Days 1-28 } \\
\hline ADFI, kg/d & 0.52 & 0.51 & 0.52 & 0.50 & 0.06 & 0.39 \\
\hline$A D G, k g / d$ & $0.19^{a}$ & $0.16^{b}$ & $0.20^{\mathrm{a}}$ & $0.19^{a}$ & 0.05 & $<0.01$ \\
\hline F/G ratio, kg/kg & $2.65^{b}$ & $3.16^{a}$ & $2.52^{b}$ & $2.73^{b}$ & 0.19 & $<0.01$ \\
\hline \multicolumn{7}{|l|}{ Days 29-56 } \\
\hline ADFI, $\mathrm{kg} / \mathrm{d}$ & 1.20 & 1.20 & 1.21 & 1.18 & 0.08 & 0.60 \\
\hline ADG, $\mathrm{kg} / \mathrm{d}$ & 0.38 & 0.43 & 0.39 & 0.38 & 0.08 & 0.23 \\
\hline $\mathrm{F} / \mathrm{G}$ ratio, $\mathrm{kg} / \mathrm{kg}$ & 2.86 & 2.88 & 3.01 & 3.12 & 0.21 & 0.45 \\
\hline \multicolumn{7}{|l|}{ Days 57-84 } \\
\hline ADFI, kg/d & 1.57 & 1.57 & 1.58 & 1.53 & 0.10 & 0.64 \\
\hline ADG, $\mathrm{kg} / \mathrm{d}$ & 0.39 & 0.34 & 0.38 & 0.39 & 0.08 & 0.19 \\
\hline F/G ratio, kg/kg & 4.04 & 4.68 & 4.31 & 4.11 & 0.25 & 0.08 \\
\hline \multicolumn{7}{|l|}{ Days 1-84 } \\
\hline ADFI, kg/d & 1.10 & 1.09 & 1.10 & 1.07 & 0.07 & 0.39 \\
\hline ADG, kg/d & 0.32 & 0.31 & 0.33 & 0.32 & 0.05 & 0.52 \\
\hline F/G ratio, kg/kg & $3.43^{\mathrm{ab}}$ & $3.57^{\mathrm{a}}$ & $3.28^{b}$ & $3.32^{b}$ & 0.15 & 0.02 \\
\hline
\end{tabular}

Means with superscripts within the same row significantly differ at $p<0.05 . n=8$.

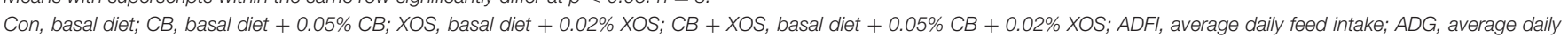
gain; BW, body weight; F:G, feed intake/body weight gain.

were selected for sample collection. The diet was removed $12 \mathrm{~h}$ before slaughtering. All the animals were sacrificed under the commercial conditions by using electrical stunning $(120 \mathrm{~V}$, $200 \mathrm{~Hz}$ ) and exsanguination. After the head, feet, tail, and internal organs were removed, the carcass was weighed and recorded to calculate the carcass yield (carcass weight/preslaughter weight $\times 100 \%)$ and then cut into two parts longitudinally. After slaughtering, fresh longissimus dorsi (LD) muscle between the sixth and seventh ribs on the right side of carcass was immediately collected for meat color, $\mathrm{pH}$ value, and marbling score determination, and then stored at $-20^{\circ} \mathrm{C}$ for analysis of chemical composition.

\section{Carcass Trait Measurement}

The backfat thickness, skin thickness, and loin eye area between the sixth and seventh ribs on the left side carcass were measured by using a Vernier caliper. The left side of carcass was weighed and then dissected into skin, skeletal muscle, fat, and bone. Carcass composition was calculated by dividing the tissue weight by the carcass weight (13).

\section{Meat Quality Assessment}

Meat quality was estimated by using meat color, $\mathrm{pH}$ value, and marbling score. The objective color of fresh meat was evaluated by using the Konica Minolta Chroma Meter (CR410, Konica Minolta Sensing Incorporation, Tokyo, Japan) with a 50-mm aperture, $\Phi 50 \mathrm{~mm}$ measurement area, and D65 light source. The $\mathrm{a}^{*}$ (redness), b* (yellowness), and $\mathrm{L}^{*}$ (lightness) values were recorded, respectively. The $\mathrm{pH}_{45 \text { min }}$ postmortem was determined by using a handheld pH meter (Russell CD700, Russell pH Ltd.,
Fife, UK) by inserting the electrode into the core of the muscle parallel to muscle fibers (14).

\section{Chemical Analysis of Skeletal Muscle}

After excess fat and fascia were removed, muscle samples were cut into thin slices, placed in a tray, dried by using a vacuum freeze dryer (50ND, Scientz, Ningbo, China), and then ground into powder by using an electric shredder. The crude protein (CP) and intramuscular fat (IMF) of the muscle samples were determined by using Kjeldahl and Soxhlet extractions with petroleum ether, respectively, according to the Association of Official Analytical Chemists methods. The hydrolyzed amino acid (AA) contents in muscle samples were determined as described previously (15) by using an AA analyzer (L8900, Hitachi, Tokyo, Japan). The fatty acid (FA) composition of LD muscle was determined according to the previously described method (16) by using a gas chromatographer (7890A, Agilent Technologies, California, USA) equipped with a flame ionization detector and a CP-Sil 88 fused silica open tube capillary column $(100 \times 0.25 \mathrm{~nm}$; Varian Chrompack, USA). The individual FA was quantified according to the peak area and expressed as a percentage of total FA.

\section{Statistical Analysis}

Data were statistically analyzed by the one-way ANOVA by using the General Linear Model (GLM) procedure of the Statistical Analysis System (SAS) 9.2 software (Institute Incorporation, Cary, North Carolina, USA). When a significant interaction effect was found, the Duncan's multiple comparison test was performed. Replicate was considered as the experimental unit. Data were expressed as treatment means with their pooled 
TABLE 3 | Effects of dietary addition with CB and XOS on carcass traits of Huanjiang mini-pigs.

\begin{tabular}{|c|c|c|c|c|c|c|}
\hline Items & Con group & CB group & XOS group & CB + XOS group & SEM & $p$ value \\
\hline \multicolumn{7}{|l|}{ Day 28 of the trial } \\
\hline Pre-slaughter weight, kg & 14.97 & 14.92 & 15.49 & 14.80 & 0.42 & 0.76 \\
\hline Carcass weight, kg & 8.04 & 7.59 & 8.13 & 7.61 & 0.35 & 0.57 \\
\hline Carcass yield, \% & 53.99 & 53.24 & 51.20 & 52.36 & 0.59 & 0.26 \\
\hline Total skin, \% & 24.45 & 22.32 & 22.84 & 23.93 & 0.49 & 0.14 \\
\hline Total bone, \% & 18.59 & 20.10 & 18.14 & 18.81 & 0.54 & 0.39 \\
\hline Total skeletal muscle, \% & 35.98 & 37.94 & 37.91 & 34.40 & 0.60 & 0.06 \\
\hline Total fat, \% & 20.76 & 18.87 & 21.11 & 21.89 & 0.62 & 0.27 \\
\hline Loin eye area, $\mathrm{cm}^{2}$ & 5.88 & 6.86 & 7.24 & 7.62 & 0.48 & 0.12 \\
\hline Skin thickness, mm & 1.79 & 1.59 & 2.13 & 2.06 & 0.26 & 0.22 \\
\hline Backfat thickness, mm & 12.81 & 11.69 & 11.50 & 10.93 & 0.48 & 0.26 \\
\hline \multicolumn{7}{|l|}{ Day 56 of the trial } \\
\hline Pre-slaughter weight, kg & $28.57^{a}$ & $24.94^{\mathrm{C}}$ & $26.21^{b c}$ & $27.39^{a b}$ & 0.46 & $<0.01$ \\
\hline Carcass weight, kg & $16.67^{a}$ & $13.61^{b}$ & $15.45^{\mathrm{ab}}$ & $14.50^{b}$ & 0.46 & 0.01 \\
\hline Carcass yield, \% & $58.20^{a}$ & $54.40^{\mathrm{b}}$ & $57.19^{a b}$ & $54.52^{b}$ & 0.62 & 0.04 \\
\hline Total skin, \% & $19.77^{b}$ & $19.54^{b}$ & $21.90^{\mathrm{a}}$ & $18.60^{b}$ & 0.44 & $<0.01$ \\
\hline Total bone, \% & $14.28^{\mathrm{b}}$ & $20.39^{a}$ & $15.84^{b}$ & $19.28^{a}$ & 0.62 & $<0.01$ \\
\hline Total skeletal muscle, \% & 33.62 & 31.58 & 31.30 & 32.13 & 0.81 & 0.82 \\
\hline Total fat, \% & 31.20 & 27.66 & 29.57 & 29.99 & 0.64 & 0.22 \\
\hline Loin eye area, $\mathrm{cm}^{2}$ & 6.90 & 5.97 & 7.08 & 6.60 & 0.44 & 0.51 \\
\hline Skin thickness, mm & $3.22^{\mathrm{a}}$ & $2.13^{b}$ & $2.44^{b}$ & $2.03^{b}$ & 0.26 & $<0.01$ \\
\hline Backfat thickness, mm & $21.88^{b}$ & $19.66^{b}$ & $21.53^{b}$ & $25.60^{a}$ & 0.63 & $<0.01$ \\
\hline \multicolumn{7}{|l|}{ Day 84 of the trial } \\
\hline Pre-slaughter weight, kg & 40.70 & 39.83 & 40.78 & 39.86 & 0.63 & 0.89 \\
\hline Carcass weight, kg & 24.45 & 23.72 & 25.40 & 24.68 & 0.49 & 0.39 \\
\hline Carcass yield, \% & $59.32^{b}$ & $59.54^{b}$ & $62.34^{a}$ & $58.94^{b}$ & 0.56 & 0.04 \\
\hline Total skin, \% & $19.09^{b}$ & $20.55^{\mathrm{b}}$ & $19.92^{b}$ & $25.24^{a}$ & 0.61 & $<0.01$ \\
\hline Total bone, \% & 14.80 & 13.23 & 14.63 & 13.16 & 0.50 & 0.24 \\
\hline Total skeletal muscle, \% & 29.69 & 29.75 & 31.03 & 29.31 & 0.66 & 0.78 \\
\hline Total fat, \% & 35.06 & 36.46 & 36.95 & 33.50 & 0.74 & 0.42 \\
\hline Loin eye area, $\mathrm{cm}^{2}$ & 10.08 & 10.92 & 12.25 & 11.43 & 0.50 & 0.20 \\
\hline Skin thickness, mm & $4.94^{\mathrm{a}}$ & $2.45^{\mathrm{b}}$ & $2.58^{b}$ & $2.60^{b}$ & 0.26 & $<0.01$ \\
\hline Backfat thickness, mm & $27.42^{\mathrm{c}}$ & $37.53^{\mathrm{a}}$ & $32.41^{b}$ & $34.26^{a b}$ & 0.76 & $<0.01$ \\
\hline
\end{tabular}

Means with superscripts within the same row significantly differ at $p<0.05 . n=8$.

Con, basal diet; $C B$, basal diet $+0.05 \% C B ;$ XOS, basal diet $+0.02 \%$ XOS; $C B+X O S$, basal diet $+0.05 \% C B+0.02 \% \times O S$.

SEM and the differences between means were considered as statistically significant at $p<0.05$.

\section{RESULTS}

\section{Growth Performance}

As shown in Table 2, no differences $(p>0.05)$ were observed in the final BW and ADFI among the four treatments. Compared with the Con group, dietary $\mathrm{CB}$ addition decreased the ADG and increased the F:G ratio at day 28 of the trial $(p<0.05)$. In addition, the $\mathrm{F}: \mathrm{G}$ ratio in the $\mathrm{CB}+\mathrm{XOS}$ group was lower $(p<$ 0.05 ) during days $1-84$ of the trial compared with the $\mathrm{CB}$ group.

\section{Carcass Trait}

As shown in Table 3, at day 56 of the trial, dietary CB or XOS addition decreased $(p<0.05)$ the preslaughter weight; CB and
$\mathrm{CB}+\mathrm{XOS}$ groups were lower $(p<0.05)$ in the carcass weight, carcass yield, and skin thickness compared with the Con group. In addition, pigs fed with $\mathrm{CB}+\mathrm{XOS}$ had a highest $(p<0.05)$ backfat thickness. Pigs fed with XOS had a higher $(p<0.05)$ carcass yield and backfat thickness at day 84 of the trial compared with fed with those Con diet. The CB, XOS, and CB + XOS groups were higher in the backfat thickness at day 84 of the trial compared with the Con group.

\section{Meat Quality}

As shown in Table 4, CB, XOS, and CB + XOS groups were higher $(p<0.05)$ in the $\mathrm{pH}_{45 \mathrm{~min}}$ and were lower $(p<0.05)$ in the marbling score at day 28 of the trial compared with the Con group. The $\mathrm{CB}+\mathrm{XOS}$ group was higher $(p<0.05)$ in the $\mathrm{a}^{*}$ value at day 56 of the trial compared with the XOS group. At day 84 of the trial, higher $(p<0.05) \mathrm{a}^{*}$ value and marbling score were 
TABLE 4 | Effects of dietary addition with CB and XOS on meat quality of Huanjiang mini-pigs.

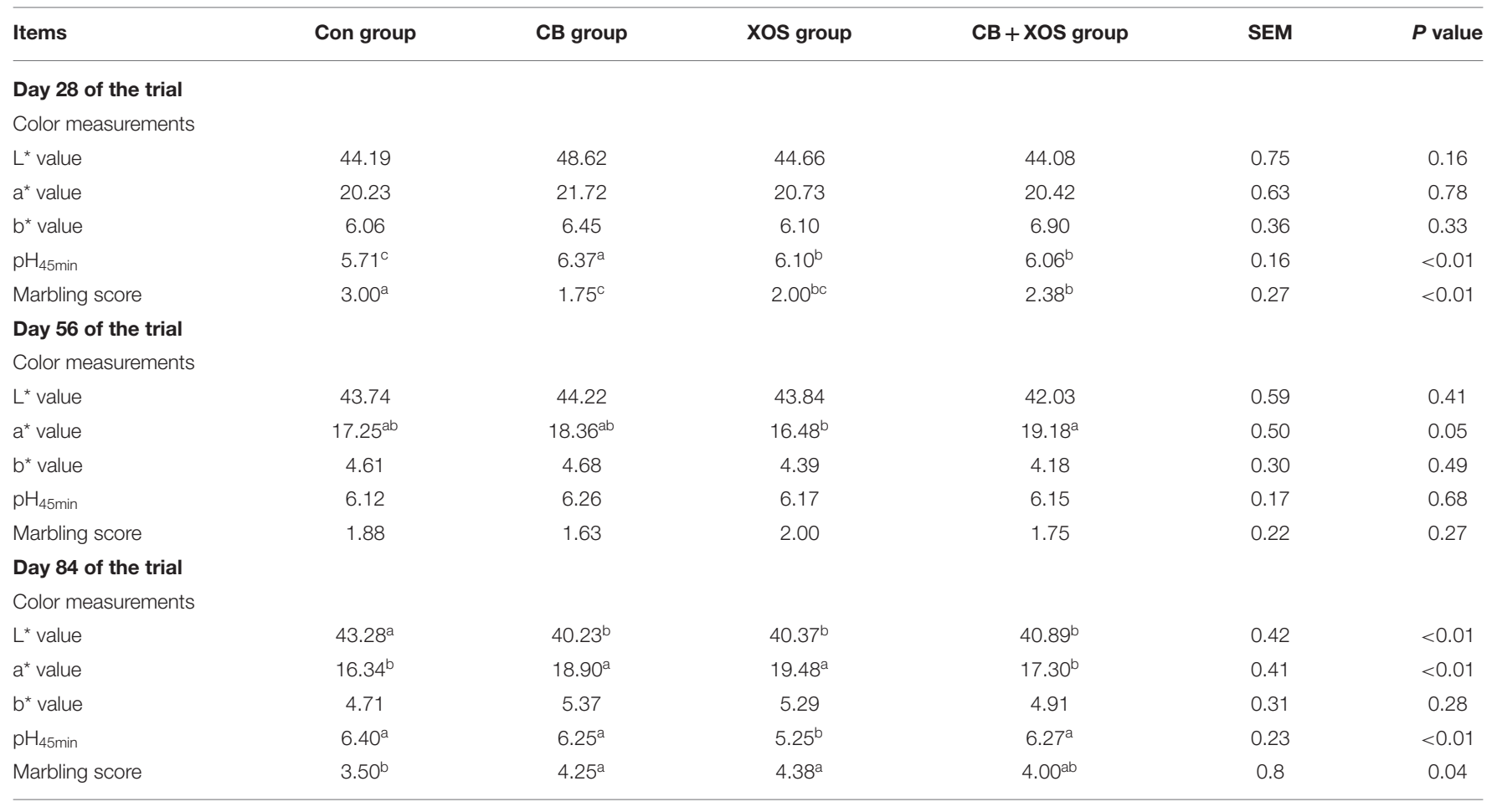

Means with superscripts within the same row significantly differ at $p<0.05 . n=8$.

Con, basal diet; $C B$, basal diet $+0.05 \%$ CB; XOS, basal diet $+0.02 \%$ XOS; $C B+X O S$, basal diet $+0.05 \% C B+0.02 \% \times O S$.

observed in $\mathrm{CB}$ and XOS groups compared with the Con group. Dietary addition with CB and/or XOS decreased $(p<0.05)$ the $\mathrm{L}^{*}$ value in muscle.

\section{Chemical Composition of Muscle}

As shown in Table 5, pigs fed with CB or XOS had lower $(p<0.05)$ contents of Glu, Ile, Leu, Met, Tyr, Val, and essential amino acid (EAA) in LD muscle at day 28 of the trial compared with the Con group. At day 56 of the trial, XOS group was higher $(p<0.05)$ in the contents of His, Lys, Met, Phe, and EAA compared with the Con group. At day 84 of the trial, dietary CB addition increased $(p<0.05)$ the contents of Asp, Met, Pro, Ser, Tyr, Val, nonessential amino acid (NEAA), and total amino acid (TAA) and XOS addition increased $(p<0.05)$ the contents of CP, Ala, Arg, Asp, Glu, Ile, Leu, Lys, Met, Pro, Ser, Thr, Tyr, Val, EAA, flavor amino acid (FAA), NEAA, and TAA in LD muscle compared with the Con group.

As shown in Table 6, at day 28 of the trial, dietary CB or XOS addition decreased $(p<0.05)$ the IMF content in LD muscle; dietary XOS addition or in combination with $\mathrm{CB}$ decreased $(p<0.05)$ the percentage of C14:0 in LD muscle compared with the Con group. In addition, dietary XOS and CB addition increased $(p<0.05)$ the percentages of C20:3n-6, C20:4n-6, C22:6n-3, and polyunsaturated fatty acid (PUFA) in LD muscle, whereas decreased $(p<0.05)$ the percentage of monounsaturated fatty acid (MUFA) compared with the Con group. At day 56 of the trial, the IMF content in LD muscle was lower $(p<0.05)$ and the C18:3n-6 percentage was higher $(p<0.05)$ in the CB and XOS groups compared with the Con group. The $\mathrm{CB}+\mathrm{XOS}$ group was higher $(p<0.05)$ in the percentage of C18:3n-6 compared with the Con group. At day 84 of the trial, the percentages of C20:1 was lower $(p<0.05)$ in the CB group compared with the Con group.

\section{DISCUSSION}

The growth performance and meat quality of pigs are influenced by the genotype and rearing conditions $(17,18)$. This study investigated the effects of dietary $\mathrm{CB}$ and XOS addition on growth performance, carcass trait, and meat quality of Huanjiang mini-pigs with different body weight (ages). Our results showed that dietary $\mathrm{CB}$ and XOS addition did not alter the final body weight of pigs, which was in line with previous studies, where they reported that dietary $\mathrm{CB}$ or XOS addition had no effects on final body weight in the broilers or pigs (19). The XOS cannot be degraded by the digestive enzymes and are metabolized by microbiota in the colon (20). In addition, XOS are competitive inhibitors of cellobiohydrolase I (21), which indicates that dietary addition with XOS may exert a negative effect on growth performance. Here, we found that XOS group showed the highest $A D G$ and lowest $F: G$ ratio at day 28 of the trial. This may be related to the fact that the XOS is sweet and more lure. Previous study also showed that the ADG of pigs fed the XOS diet was higher than pigs fed the Con diet (22). However, we found that dietary CB addition has a negative effect on the F:G during the entire trial period. Chen et al. (23) showed that dietary CB addition had no effect on F:G of 
TABLE 5 | Effects of dietary addition with CB and XOS on crude protein (CP) content and amino acid composition of longissimus dorsi muscle of Huanjiang mini-pigs (100 $\mathrm{g}$ fresh muscle).

\begin{tabular}{|c|c|c|c|c|c|c|}
\hline Items & Con group & CB group & XOS group & $\mathrm{CB}+\mathrm{XOS}$ group & SEM & $p$ value \\
\hline \multicolumn{7}{|c|}{ Day 28 of the trial } \\
\hline $\mathrm{CP}$ & 17.49 & 17.30 & 17.29 & 17.76 & 0.30 & 0.53 \\
\hline \multicolumn{7}{|l|}{ EAA } \\
\hline His & $0.85^{a}$ & $0.76^{b}$ & $0.81^{\mathrm{ab}}$ & $0.85^{\mathrm{a}}$ & 0.08 & 0.02 \\
\hline Ile & $0.99^{a}$ & $0.91^{b}$ & $0.93^{\mathrm{b}}$ & $0.95^{b}$ & 0.06 & $<0.01$ \\
\hline Leu & $1.63^{\mathrm{a}}$ & $1.51^{\mathrm{b}}$ & $1.54^{\mathrm{b}}$ & $1.58^{\mathrm{ab}}$ & 0.09 & $<0.01$ \\
\hline Lys & 1.80 & 1.70 & 1.72 & 1.78 & 0.10 & 0.10 \\
\hline Met & $0.52^{\mathrm{a}}$ & $0.46^{\mathrm{c}}$ & $0.47^{\mathrm{bc}}$ & $0.51^{\mathrm{ab}}$ & 0.07 & 0.01 \\
\hline Phe & 0.82 & 0.77 & 0.78 & 0.82 & 0.08 & 0.14 \\
\hline Thr & 0.90 & 0.85 & 0.86 & 0.89 & 0.07 & 0.09 \\
\hline Val & $1.05^{\mathrm{a}}$ & $0.98^{\mathrm{b}}$ & $0.99^{b}$ & $1.02^{\mathrm{ab}}$ & 0.07 & 0.02 \\
\hline \multicolumn{7}{|l|}{ NEAA } \\
\hline Ala & 1.12 & 1.08 & 1.07 & 1.10 & 0.07 & 0.19 \\
\hline Arg & 1.28 & 1.24 & 1.24 & 1.28 & 0.08 & 0.33 \\
\hline Asp & 1.83 & 1.75 & 1.77 & 1.82 & 0.10 & 0.19 \\
\hline Glu & $2.93^{\mathrm{a}}$ & $2.77^{\mathrm{b}}$ & $2.79^{b}$ & $2.89^{a b}$ & 0.12 & 0.05 \\
\hline Gly & 0.87 & 0.95 & 0.90 & 0.92 & 0.08 & 0.06 \\
\hline Pro & 0.72 & 0.74 & 0.72 & 0.72 & 0.06 & 0.56 \\
\hline Ser & 0.73 & 0.70 & 0.70 & 0.72 & 0.06 & 0.17 \\
\hline Tyr & $0.67^{a}$ & $0.61^{b}$ & $0.63^{b}$ & $0.64^{\mathrm{ab}}$ & 0.06 & $<0.01$ \\
\hline EAA & $8.55^{a}$ & $7.95^{c}$ & $8.11^{b c}$ & $8.38^{\mathrm{ab}}$ & 0.21 & 0.01 \\
\hline NEAA & 10.01 & 9.65 & 9.82 & 10.10 & 0.25 & 0.34 \\
\hline FAA & 8.03 & 7.80 & 7.78 & 8.00 & 0.20 & 0.30 \\
\hline TAA & 18.55 & 17.60 & 17.94 & 18.49 & 0.31 & 0.08 \\
\hline \multicolumn{7}{|c|}{ Day 56 of the trial } \\
\hline $\mathrm{CP}$ & $19.08^{b}$ & $18.85^{b}$ & $19.47^{b}$ & $20.27^{a}$ & 0.27 & $<0.01$ \\
\hline \multicolumn{7}{|l|}{ EAA } \\
\hline His & $0.88^{c}$ & $0.92^{\mathrm{c}}$ & $0.98^{b}$ & $1.04^{a}$ & 0.07 & $<0.01$ \\
\hline Ile & $1.05^{b}$ & $1.06^{b}$ & $1.11^{\mathrm{ab}}$ & $1.14^{\mathrm{a}}$ & 0.08 & $<0.01$ \\
\hline Leu & $1.69^{b}$ & $1.72^{b}$ & $1.77^{\mathrm{ab}}$ & $1.83^{\mathrm{a}}$ & 0.10 & 0.01 \\
\hline Lys & $1.93^{\mathrm{c}}$ & $1.95^{\mathrm{bc}}$ & $2.03^{\mathrm{ab}}$ & $2.11^{\mathrm{a}}$ & 0.11 & $<0.01$ \\
\hline Met & $0.53^{b}$ & $0.57^{\mathrm{ab}}$ & $0.60^{a}$ & $0.59^{a}$ & 0.070 & 0.01 \\
\hline Phe & $0.89^{b}$ & $0.89^{b}$ & $0.95^{a}$ & $0.99^{a}$ & 0.07 & $<0.01$ \\
\hline Thr & $0.95^{b}$ & $0.98^{\mathrm{b}}$ & $1.00^{\mathrm{ab}}$ & $1.04^{\mathrm{a}}$ & 0.08 & 0.01 \\
\hline Val & $1.10^{\mathrm{b}}$ & $1.10^{\mathrm{b}}$ & $1.15^{\mathrm{b}}$ & $1.20^{\mathrm{a}}$ & 0.08 & $<0.01$ \\
\hline \multicolumn{7}{|l|}{ NEAA } \\
\hline Ala & $1.14^{\mathrm{b}}$ & $1.17^{\mathrm{ab}}$ & $1.17^{\mathrm{ab}}$ & $1.22^{\mathrm{a}}$ & 0.08 & 0.04 \\
\hline Arg & $1.36^{b}$ & $1.38^{\mathrm{b}}$ & $1.42^{\mathrm{ab}}$ & $1.47^{\mathrm{a}}$ & 0.09 & 0.02 \\
\hline Asp & $1.94^{b}$ & $1.99^{b}$ & $2.04^{\mathrm{ab}}$ & $2.12^{\mathrm{a}}$ & 0.11 & $<0.01$ \\
\hline Glu & 3.07 & 3.16 & 3.22 & 3.31 & 0.15 & 0.07 \\
\hline Gly & $0.90^{c}$ & $0.95^{a b}$ & $0.93^{b c}$ & $0.99^{a}$ & 0.07 & $<0.01$ \\
\hline Pro & 0.73 & 0.75 & 0.76 & 0.78 & 0.07 & 0.06 \\
\hline Ser & $0.75^{b}$ & $0.78^{a b}$ & $0.78^{\mathrm{ab}}$ & $0.81^{a}$ & 0.07 & 0.04 \\
\hline Tyr & $0.69^{b}$ & $0.70^{b}$ & $0.73^{\mathrm{ab}}$ & $0.75^{a}$ & 0.070 & 0.01 \\
\hline EAA & $9.11^{b}$ & $9.19^{b}$ & $9.58^{a}$ & $9.94^{a}$ & 0.21 & $<0.01$ \\
\hline NEAA & $10.85^{b}$ & $10.86^{b}$ & $11.03^{\mathrm{ab}}$ & $11.46^{a}$ & 0.24 & 0.04 \\
\hline FAA & $8.51^{\mathrm{b}}$ & $8.66^{b}$ & $8.77^{\mathrm{ab}}$ & $9.12^{\mathrm{a}}$ & 0.21 & 0.02 \\
\hline TAA & $19.96^{b}$ & $20.06^{b}$ & $20.61^{\mathrm{ab}}$ & $21.40^{\mathrm{a}}$ & 0.31 & $<0.01$ \\
\hline
\end{tabular}


TABLE 5 | Continued

\begin{tabular}{|c|c|c|c|c|c|c|}
\hline Items & Con group & CB group & XOS group & CB + XOS group & SEM & $p$ value \\
\hline \multicolumn{7}{|c|}{ Day 84 of the trial } \\
\hline $\mathrm{CP}$ & $18.87^{b}$ & $19.49^{a b}$ & $19.77^{a}$ & $18.94^{b}$ & 0.27 & 0.01 \\
\hline \multicolumn{7}{|l|}{ EAA } \\
\hline His & 0.96 & 1.00 & 1.01 & 0.95 & 0.08 & 0.05 \\
\hline lle & $1.05^{b}$ & $1.09^{a b}$ & $1.13^{\mathrm{a}}$ & $1.06^{b}$ & 0.08 & 0.03 \\
\hline Leu & $1.71^{\mathrm{b}}$ & $1.78^{a b}$ & $1.83^{a}$ & $1.72^{b}$ & 0.10 & 0.03 \\
\hline Lys & $1.94^{\mathrm{b}}$ & $2.01^{a b}$ & $2.08^{a}$ & $1.96^{b}$ & 0.11 & 0.04 \\
\hline Met & $0.51^{b}$ & $0.59^{a}$ & $0.58^{a}$ & $0.52^{b}$ & 0.06 & $<0.01$ \\
\hline Phe & 0.89 & 0.90 & 0.93 & 0.88 & 0.07 & 0.08 \\
\hline Thr & $0.97^{b}$ & $1.00^{a b}$ & $1.03^{a}$ & $0.96^{b}$ & 0.07 & $<0.01$ \\
\hline Val & $1.15^{\mathrm{b}}$ & $1.21^{\mathrm{a}}$ & $1.23^{\mathrm{a}}$ & $1.13^{b}$ & 0.07 & $<0.01$ \\
\hline \multicolumn{7}{|l|}{ NEAA } \\
\hline Ala & $1.17^{\mathrm{b}}$ & $1.21^{\mathrm{ab}}$ & $1.24^{\mathrm{a}}$ & $1.19^{\mathrm{b}}$ & 0.08 & 0.04 \\
\hline Arg & $1.36^{b}$ & $1.42^{\mathrm{ab}}$ & $1.45^{\mathrm{a}}$ & $1.37^{b}$ & 0.09 & 0.03 \\
\hline Asp & $2.00^{\mathrm{b}}$ & $2.09^{a}$ & $2.13^{a}$ & $1.97^{\mathrm{b}}$ & 0.09 & $<0.01$ \\
\hline Glu & $3.09^{b}$ & $3.21^{\mathrm{ab}}$ & $3.32^{a}$ & $3.12^{b}$ & 0.14 & 0.08 \\
\hline Gly & 0.92 & 0.94 & 0.96 & 0.90 & 0.08 & 0.14 \\
\hline Pro & $0.75^{\mathrm{b}}$ & $0.79^{a}$ & $0.79^{a}$ & $0.76^{a b}$ & 0.06 & 0.50 \\
\hline Ser & $0.76^{b}$ & $0.81^{a}$ & $0.82^{a}$ & $0.77^{\mathrm{b}}$ & 0.06 & $<0.01$ \\
\hline Tyr & $0.69^{b}$ & $0.74^{\mathrm{a}}$ & $0.75^{a}$ & $0.69^{b}$ & 0.07 & $<0.01$ \\
\hline EAA & $9.17^{\mathrm{b}}$ & $9.59^{a b}$ & $9.82^{\mathrm{a}}$ & $9.18^{\mathrm{b}}$ & 0.23 & $<0.01$ \\
\hline NEAA & $10.74^{b}$ & $11.47^{a}$ & $11.46^{a}$ & $10.82^{b}$ & 0.24 & $<0.01$ \\
\hline FAA & $8.54^{b}$ & $8.87^{a b}$ & $9.11^{a}$ & $8.55^{b}$ & 0.21 & $<0.01$ \\
\hline TAA & $19.91^{b}$ & $21.06^{\mathrm{a}}$ & $21.28^{\mathrm{a}}$ & $20.00^{b}$ & 0.31 & $<0.01$ \\
\hline
\end{tabular}

Means with superscripts within the same row significantly differ at $p<0.05 . n=8$.

Con, basal diet; CB, basal diet + 0.05\% CB; XOS, basal diet + 0.02\% XOS; CB + XOS, basal diet + 0.05\% CB + 0.02\% XOS.

Essential amino acid $(E A A)=H i s+l l e+L e u+L y s+M e t+P h e+T h r+V a l$.

Nonessential amino acid (NEAA) $=$ Arg + Asp + Ala + Glu + Gly + Pro + Ser + Tyr .

Flavor amino acid $(F A A)=A l a+A s p+A r g+$ Glu + Gly.

Total amino acid $(T A A)=E A A+N E A A$.

piglets; by contrast, Song et al. (24) reported that dietary CB addition could decrease the F:G. These findings suggest that the effect of dietary $\mathrm{CB}$ addition on $\mathrm{F}: \mathrm{G}$ in animals remains highly controversial and further investigations are needed to elucidate this effect. In addition, dietary XOS could ameliorate the negative effects of $\mathrm{CB}$ on $\mathrm{F}: \mathrm{G}$, which might explain that the XOS are nondigestible oligosaccharides, most of the $\mathrm{CB}$ can utilize XOS to produce bioactive metabolites (including SCFA and bioamines), and improve the consumption of intestinal nutrients.

Meat quality is one of the most important economic traits of pigs and can be reflected by the color and $\mathrm{pH}$ of the muscles (25). In this study, dietary XOS addition increased carcass yield at day 84 of the trial, but not days 28 and 56 of the trial, indicating that the XOS increased carcass yield in a time-dependent manner. In addition, dietary addition with $\mathrm{CB}$ and XOS increased the $\mathrm{pH}_{45 \mathrm{~min}}$ value and decreased the $\mathrm{L}^{*}$ value at days 56 and 84 of the trial, respectively, suggesting that the meat $\mathrm{pH}$ and color were improved by $\mathrm{CB}$ and XOS addition. Scheffler et al. (26) reported that inhibition of mitochondrial enzyme activity contributes to accelerated $\mathrm{pH}$ decline of meat. The increased
$\mathrm{pH}_{45 \text { min }}$ value induced by $\mathrm{CB}$ and XOS addition might be due to the improvement of mitochondrial function $(27,28)$.

It is well documented that IMF or marbling is largely involved in quality and acceptability of meat, particularly meat nutrition, tenderness, juiciness, taste, and conservation ability (29). In this study, no difference was observed in the IMF content between the Con group and the XOS + CB group, suggesting that dietary $\mathrm{XOS}$ and $\mathrm{CB}$ addition is not a feasible approach to improve meat quality by increasing the IMF content. Meat has a great potential for delivering important nutrients such as proteins, AA, FA, and vitamins (30). The AA content in muscle represents the protein quality of meat. Furthermore, some AA plays key roles in the aroma and flavor profiles of meat. For example, Glu and Asp show a pleasantly fresh taste; Gly, Ala, and Ser present a sweet taste; Arg, Leu, Iso, Val, Phe, Met, and His present a bitter taste; Lys and Pro contribute sweet and bitter tastes; and others show sour or salty tastes (31). In this study, dietary CB and XOS addition increased the muscular contents of CP and AAs at day 56 of the trial. In support of our findings, Liu et al. (32) showed that CB addition increased the contents of EAAs and flavor AAs in muscle. Several previous studies showed that 
TABLE 6 | Effects of dietary addition with CB and XOS on intramuscular fat (IMF) content and fatty acid composition of longissimus dorsi muscle of Huanjiang mini-pigs (\% total fatty acids).

\begin{tabular}{|c|c|c|c|c|c|c|}
\hline Items & Con group & CB group & XOS group & $\mathrm{CB}+\mathrm{XOS}$ group & SEM & $p$ value \\
\hline \multicolumn{7}{|l|}{ Day 28 of the trial } \\
\hline IMF, g/100 g fresh muscle & $6.50^{\mathrm{a}}$ & $3.83^{b}$ & $3.80^{\mathrm{b}}$ & $6.72^{\mathrm{a}}$ & 0.44 & $<0.01$ \\
\hline C14:0 & $1.17^{\mathrm{a}}$ & $1.08^{\mathrm{ab}}$ & $1.00^{\mathrm{b}}$ & $0.84^{\mathrm{C}}$ & 0.13 & $<0.01$ \\
\hline C16:0 & 25.08 & 24.95 & 24.16 & 23.42 & 0.41 & 0.07 \\
\hline C16:1 & 3.66 & 3.40 & 3.44 & 2.65 & 0.32 & 0.10 \\
\hline C17:0 & 1.16 & 0.96 & 0.88 & 0.94 & 0.20 & 0.35 \\
\hline C18:0 & 13.69 & 13.57 & 13.52 & 14.36 & 0.28 & 0.06 \\
\hline C18:1n-9c & 29.84 & 30.65 & 29.11 & 25.58 & 0.72 & 0.09 \\
\hline C18:2n-6c & 17.77 & 17.05 & 18.54 & 19.83 & 0.59 & 0.25 \\
\hline C18:3n-6 & 0.11 & 0.10 & 0.11 & 0.12 & 0.06 & 0.59 \\
\hline C20:0 & 0.21 & 0.26 & 0.22 & 0.22 & 0.07 & 0.19 \\
\hline C2O:1 & 0.65 & 0.64 & 0.60 & 0.55 & 0.14 & 0.58 \\
\hline C20:3n-6 & $0.49^{b}$ & $0.41^{\mathrm{b}}$ & $0.43^{\mathrm{b}}$ & $0.78^{\mathrm{a}}$ & 0.12 & $<0.01$ \\
\hline C20:4n-6 & $5.53^{\mathrm{b}}$ & $4.52^{\mathrm{b}}$ & $5.75^{\mathrm{b}}$ & $9.45^{\mathrm{a}}$ & 0.49 & $<0.01$ \\
\hline C22:6n-3 & $0.28^{\mathrm{b}}$ & $0.23^{b}$ & $0.29^{b}$ & $0.51^{\mathrm{a}}$ & 0.13 & $<0.01$ \\
\hline $\mathrm{SFA}^{1}$ & 41.32 & 40.83 & 39.80 & 39.77 & 0.42 & 0.09 \\
\hline MUFA $^{2}$ & $34.15^{\mathrm{a}}$ & $34.69^{a}$ & $33.14^{\mathrm{a}}$ & $27.28^{b}$ & 0.72 & $<0.01$ \\
\hline PUFA $^{3}$ & $24.18^{b}$ & $22.31^{b}$ & $25.11^{b}$ & $30.69^{a}$ & 0.76 & $<0.01$ \\
\hline \multicolumn{7}{|l|}{ Day 56 of the trial } \\
\hline IMF, g/100 g fresh muscle & $4.92^{\mathrm{a}}$ & $3.36^{\mathrm{b}}$ & $3.27^{\mathrm{b}}$ & $4.23^{\mathrm{ab}}$ & 0.35 & 0.01 \\
\hline C14:0 & 1.14 & 1.02 & 1.05 & 1.07 & 0.16 & 0.70 \\
\hline C16:0 & 27.60 & 26.90 & 26.56 & 26.31 & 0.36 & 0.11 \\
\hline C16:1 & 2.43 & 2.93 & 2.63 & 2.67 & 0.24 & 0.22 \\
\hline C17:0 & $0.80^{\mathrm{b}}$ & $1.06^{\mathrm{a}}$ & $0.74^{b}$ & $0.73^{b}$ & 0.12 & $<0.01$ \\
\hline C18:0 & 15.39 & 14.65 & 14.41 & 14.74 & 0.39 & 0.46 \\
\hline C18:1n-9c & 31.52 & 29.28 & 30.92 & 30.42 & 0.69 & 0.69 \\
\hline C18:2n-6c & 14.37 & 15.56 & 14.71 & 16.01 & 0.64 & 0.75 \\
\hline C18:3n-6 & $0.10^{\mathrm{b}}$ & $0.17^{a}$ & $0.14^{a}$ & $0.15^{\mathrm{a}}$ & 0.06 & $<0.01$ \\
\hline C20:0 & $0.20^{\mathrm{b}}$ & $0.24^{a}$ & $0.20^{\mathrm{b}}$ & $0.22^{\mathrm{ab}}$ & 0.06 & 0.04 \\
\hline C2O:1 & 0.69 & 0.65 & 0.66 & 0.63 & 0.14 & 0.92 \\
\hline C20:3n-6 & 0.48 & 0.61 & 0.52 & 0.57 & 0.143 & 0.40 \\
\hline$C 20: 4 n-6$ & 4.46 & 6.06 & 5.27 & 5.15 & 0.45 & 0.31 \\
\hline C22:6n-3 & $0.20^{\mathrm{ab}}$ & $0.22^{\mathrm{ab}}$ & $0.18^{\mathrm{b}}$ & $0.24^{a}$ & 0.07 & 0.04 \\
\hline SFA & 45.12 & 43.86 & 42.96 & 43.07 & 0.46 & 0.06 \\
\hline MUFA & 34.63 & 32.86 & 34.21 & 33.72 & 0.73 & 0.86 \\
\hline PUFA & 19.61 & 22.61 & 20.83 & 22.12 & 0.78 & 0.62 \\
\hline \multicolumn{7}{|l|}{ Day 84 of the trial } \\
\hline IMF, g/100 g fresh muscle & 5.60 & 4.17 & 4.83 & 5.06 & 0.45 & 0.40 \\
\hline C14:0 & 1.25 & 1.22 & 1.23 & 1.31 & 0.15 & 0.82 \\
\hline C16:0 & 26.49 & 26.65 & 26.23 & 26.92 & 0.38 & 0.70 \\
\hline C16:1 & 3.24 & 3.05 & 3.21 & 2.85 & 0.27 & 0.54 \\
\hline C17:0 & 0.60 & 0.57 & 0.50 & 0.60 & 0.12 & 0.38 \\
\hline C18:0 & 13.47 & 13.92 & 13.68 & 14.56 & 0.33 & 0.11 \\
\hline C18:1n-9c & 36.59 & 33.72 & 35.65 & 33.13 & 0.61 & 0.09 \\
\hline C18:2n-6c & 11.54 & 13.54 & 13.85 & 12.99 & 0.57 & 0.31 \\
\hline C18:3n-6 & 0.12 & 0.11 & 0.12 & 0.11 & 0.06 & 0.91 \\
\hline C20:0 & 0.23 & 0.23 & 0.21 & 0.26 & 0.07 & 0.06 \\
\hline C2O:1 & $0.81^{a}$ & $0.66^{b}$ & $0.75^{a}$ & $0.74^{\mathrm{ab}}$ & 0.10 & $<0.01$ \\
\hline C20:3n-6 & 0.12 & 0.11 & 0.12 & 0.11 & 0.06 & 0.90 \\
\hline
\end{tabular}


TABLE 6 | Continued

\begin{tabular}{|c|c|c|c|c|c|c|}
\hline Items & Con group & CВ group & XOS group & CB + XOS group & SEM & $p$ value \\
\hline C20:4n-6 & 0.81 & 0.65 & 0.75 & 0.81 & 0.13 & 0.06 \\
\hline C22:6n-3 & 0.42 & 0.52 & 0.56 & 0.52 & 0.13 & 0.18 \\
\hline SFA & 3.76 & 4.68 & 4.50 & 4.76 & 0.43 & 0.55 \\
\hline MUFA & $0.10^{\mathrm{b}}$ & $0.17^{a}$ & $0.18^{a}$ & $0.13^{b}$ & 0.06 & $<0.01$ \\
\hline PUFA & 42.05 & 42.60 & 41.85 & 43.65 & 0.46 & 0.15 \\
\hline
\end{tabular}

Means with superscripts within the same row significantly differ at $p<0.05 . n=8$.

Con, basal diet; $C B$, basal diet $+0.05 \%$ CB; XOS, basal diet $+0.02 \%$ XOS; $C B+X O S$, basal diet $+0.05 \%$ CB $+0.02 \%$ XOS.

Saturated fatty acids (SFAs) $=$ C14:0 + C16:0 + C17:0 + C18:0 + C20:0.

Monounsaturated fatty acids (MUFAs) $=$ C16:1 + C18:1C-9 + C20:1.

Polyunsaturated fatty acids (PUFAs) $=$ C18:2n-6c + C18:3n-6 + C20:3n-6 + C20:4n-6.

dietary $\mathrm{CB}$ and XOS could improve the intestine development $(33,34)$. Therefore, we suspected that the increased CP and AAs contents in muscle might be due to the enhancement of intestinal absorption ability. The branched-chain amino acids (BCAAs), including Leu, Ile, and Val, are important components of the body proteins and play important roles in regulating cell growth and metabolism. In addition, the BCAA could promote gluconeogenesis and provide energy for body (35). In this study, the BCAAs contents in muscle were increased by dietary XOS addition at day 84 of the trial, suggesting that the nutritional value and flavor of pork are improved by dietary CB and XOS addition.

The FAs also play important roles in flavor generation. However, excessive intake of saturated fatty acid (SFA) would increase the prevalence of cardiovascular diseases. Therefore, reduced SFA percentage and increased unsaturated FA percentage in meat could improve pork quality (36). In this study, dietary $\mathrm{CB}$ and XOS addition decreased the percentage of C14:0 and increased the percentages of C18:3n-6, C20:3n6, C20:4n-6, C22:6n-3, and PUFA in muscle at day 28 of the trial. These findings were in line with Liu et al. (32), who reported that $\mathrm{CB}$ addition increased the concentrations of C20:4n-6, C22:6n-3, and PUFA in breast muscle. Therefore, dietary $\mathrm{CB}$ and XOS addition might be a feasible strategy for developing high quality meat with healthier lipid contents. The CB is a butyrate-producing probiotic and dietary XOS addition could increase the butyrate concentration in the cecum $(22,37)$. Butyrate was shown to modulate lipid metabolism (38). These evidences suggest that the changed FA profile in muscle may be due to the butyrate production in pigs fed with $\mathrm{CB}$ and XOS. However, the mechanisms require further study.

In conclusion, dietary $\mathrm{CB}$ addition improves the meat color and marbling score and increases the contents of Met, Val, Pro, and Try in muscle at day 84 of the trial; dietary XOS addition decreased the values of $\mathrm{L}^{*}$ and $\mathrm{pH}_{45 \mathrm{~min}}$ and increased the

\section{REFERENCES}

1. Liu YY, Kong XF, Jiang GL, Tan BE, Deng JP, Yang XJ, et al. Effects of dietary protein/energy ratio on growth performance, carcass trait, meat quality, and plasma metabolites in pigs of different genotypes. contents of AAs and percentage of MUFA in LD muscle; dietary $\mathrm{CB}$ and XOS addition did not alter the growth performance of pigs, but increased the contents of AAs and percentage of PUFA in LD muscle. These findings suggested that dietary CB and/or XOS addition has important complementary advantages for improving pork quality.

\section{DATA AVAILABILITY STATEMENT}

The raw data supporting the conclusions of this article will be made available by the authors, without undue reservation.

\section{ETHICS STATEMENT}

The animal study was reviewed and approved by Animal Care and Use Committee of the Institute of Subtropical Agriculture, Chinese Academy of Sciences.

\section{AUTHOR CONTRIBUTIONS}

$\mathrm{XK}$ and XH designed the study. QC, WT, and HJ carried out the animal experiments. QC and MG conducted the sample analysis. $\mathrm{QC}$ and $\mathrm{CH}$ performed the data collection and analysis. QC, $\mathrm{CH}$, and XK drafted the manuscript. All authors have read and approved the final manuscript.

\section{FUNDING}

This study was jointly supported by grants from the Special Funds for Construction of Innovative Provinces in Hunan Province (2019RS3022), the Industry and Research Talent Support Project from Wang Kuancheng of the Chinese Academy of Sciences, and the STS Regional Key Project of the Chinese Academy of Sciences (KFJ-STS-QYZD-052). 
3. Brameld JM, Parr T. Improving efficiency in meat production. Proc Nutr Soc. (2016) 75:242-6. doi: 10.1017/S0029665116000161

4. Bäckhed F, Ding H, Wang T, Hooper L, Koh GY, Nagy A, et al. The gut microbiota as an environmental factor that regulates fat storage. Proc Natl Acad Sci USA. (2004) 101:15718-23. doi: 10.1073/pnas.04070 76101

5. Parséus A, Sommer N, Sommer F, Caesar R, Molinaro A, Ståhlman M, et al. Microbiota-induced obesity requires farnesoid X receptor. Gut. (2017) 66:429-37. doi: 10.1136/gutjnl-2015-310283

6. Claesson MJ, Jeffery IB, Conde S, Power SE, O'Connor EM, Cusack S, et al. Gut microbiota composition correlates with diet and health in the elderly. Nature. (2012) 488:178-84. doi: 10.1038/nature11319

7. Patel S, Goyal A. Functional oligosaccharides: production, properties and applications. World J Microbiol Biotechnol. (2010) 27:1119-28. doi: 10.1007/s11274-010-0558-5

8. Kong Q, He GQ, Jia JL, Zhu QL, Ruan H. Oral administration of Clostridium butyricum for modulating gastrointestinal microflora in mice. Curr Microbiol. (2011) 62:512-7. doi: 10.1007/s00284-010-9737-8

9. Liao XD, Wu RJ, Ma G, Zhao LM, Zheng ZJ, Zhang RJ. Effects of Clostridium butyricum on antioxidant properties, meat quality and fatty acid composition of broiler birds. Lipids Health Dis. (2015) 14:3644. doi: 10.1186/s12944-015-0035-0

10. Broekaert WF, Courtin CM, Verbeke K, Van de Wiele T, Verstraete W, Delcour JA. Prebiotic and other health-related effects of cereal-derived arabinoxylans, arabinoxylan-oligosaccharides, and xylooligosaccharides. Critic Rev Food Technol. (2011) 51:178-94. doi: 10.1080/104083909030 44768

11. Morrison DJ and Preston T. Formation of short chain fatty acids by the gut microbiota and their impact on human metabolism. Gut Microbes. (2016) 7:189-200. doi: 10.1080/19490976.2015.1134082

12. Ji Y, Guo Q, Yin Y, Blachier F, Kong X. Dietary proline supplementation alters colonic luminal microbiota and bacterial metabolite composition between days 45 and 70 of pregnancy in Huanjiang mini-pigs. J Anim Sci Biotechnol. (2018) 9:18. doi: 10.1186/s40104-018-0233-5

13. AOAC. (2000). Official Methods of Analysis (17th edition). Gaithersburg, MD: Association of Analytical Communities.

14. Hu CJ, Jiang QY, Zhang T, Yin YL, Li FN, Deng JP, et al. Dietary supplementation with arginine and glutamic acid modifies growth performance, carcass traits, and meat quality in growing-finishing pigs. J Anim Sci. (2017) 95:2680-9. doi: 10.2527/jas.2017.1388

15. Liu YY, Li FN, Kong XF, Tan B, Li YH, Duan YH, et al. Signaling pathways related to protein synthesis and amino acid concentration in pig skeletal muscles depend on the dietary protein level, genotype and developmental stages. PLoS ONE. (2015) 10:e0138277. doi: 10.1371/journal.pone.0138277

16. Li FN, Duan YH, Li YH, Tang YL, Geng MM, Oladele OA, et al. Effects of dietary n-6:n-3 PUFA ratio on fatty acid composition, free amino acid profile and gene expression of transporters in finishing pigs. Br J Nutr. (2015) 113:739-48. doi: 10.1017/S0007114514004346

17. Teye GA, Sheard PR, Whittington FM, Nute GR, Stewart A, Wood JD. Influence of dietary oils and protein level on pork quality. 1. Effects on muscle fatty acid composition. carcass, meat and eating quality. Meat Sci. (2006) 73:157-65. doi: 10.1016/j.meatsci.2005.11.010

18. Suarez-Belloch J, Sanz MA, Joy M, Latorre MA. Impact of increasing dietary energy level during the finishing period on growth performance, pork quality and fatty acid profile in heavy pigs. Meat Sci. (2013) 93:796801. doi: $10.1016 /$ j.meatsci.2012.12.006

19. Zhang BK, Yang X, Guo YM, Long FY. Effects of dietary lipids and Clostridium butyricumon the performance and the digestive tract of broiler chickens. Arch Anim Nutr. (2011) 65:329-39. doi: 10.1080/1745039X.2011. 568274

20. Christophersen CT, Petersen A, Licht TR, Conlon MA. Xylo-oligosaccharides and inulin affect genotoxicity and bacterial populations differently in a human colonic simulator challenged with soy protein. Nutrients. (2013) 5:374056. doi: 10.3390/nu5093740

21. Zhang J, Viikari L. Xylo-oligosaccharides are competitive inhibitors of cellobiohydrolase I from Thermoascus aurantiacus. Bioresour Technol. (2012) 117:286-91. doi: 10.1016/j.biortech.2012.04.072
22. Chen Y, Xie Y, Zhong R, Liu L, Lin C, Xiao L, et al. Effects of xylo-oligosaccharides on growth and gut microbiota as potential replacements for antibiotic in weaning piglets. Front Microbiol. (2021) 12:641172. doi: 10.3389/fmicb.2021.641172

23. Chen L, Li S, Zheng J, Li W, Jiang X, Zhao X, et al. Effects of dietary Clostridium butyricum supplementation on growth performance, intestinal development, and immune response of weaned piglets challenged with lipopolysaccharide. J Anim Sci Biotechnol. (2018) 9:62. doi: 10.1186/s40104-018-0275-8

24. Song ZF, Wu TX, Cai LS, Zhang LJ, Zheng XD. Effects of dietary supplementation with clostridium butyricum on the growth performance and humoral immune response in Miichthys miiuy. J Zhejiang Univ Sci B. (2006) 7:596-602. doi: 10.1631/jzus.2006.B0596

25. Rosenvold K, Andersen HJ. Factors of significance for pork qualitya review. Meat Sci. (2003) 64:219-37. doi: 10.1016/S0309-1740(02)0 0186-9

26. Scheffler TL, Matarneh SK, England EM, Gerrard DE. Mitochondria influence postmortem metabolism and $\mathrm{pH}$ in an in vitro model. Meat Sci. (2015) 110:118-25. doi: 10.1016/j.meatsci.2015. 07.007

27. Jia L, Li D, Feng N, Shamoon M, Sun Z, Ding L, et al. Antidiabetic effects of Clostridium butyricum CGMCC0313.1 through promoting the growth of gut butyrate-producing bacteria in type 2 diabetic mice. Sci Rep. (2013) 7:7046. doi: 10.1038/s41598-017-0 7335-0

28. Lensu S, Pariyani R, Mäkinen E, Yang B, Saleem W, Munukka E, et al. Prebiotic xylo-oligosaccharides ameliorate high-fat-diet-induced hepatic steatosis in rats. Nutrients. (2020) 12:3225. doi: 10.3390/nu121 13225

29. Yang X, Zhang B, Guo Y, Jiao P, Long F. Effects of dietary lipids and Clostridium butyricum on fat deposition and meat quality of broiler chickens. Poult Sci. (2010) 89:254-60. doi: 10.3382/ps.2009-00234

30. Pereira PM, Vicente AF. Meat nutritional composition and nutritive role in the human diet. Meat Sci. (2013) 93:586-92. doi: 10.1016/j.meatsci.2012. 09.018

31. Lorenzo JM, Franco D. Fat effect on physico-chemical, microbial and textural changes through the manufactured of dry-cured foal sausage lipolysis, proteolysis and sensory properties. Meat Sci. (2012) 92:704-14. doi: 10.1016/j.meatsci.2012. 06.026

32. Liu Y, Li Y, Feng X, Wang Z, Xia Z. Dietary supplementation with Clostridium butyricum modulates serum lipid metabolism, meat quality, and the amino acid and fatty acid composition of Peking ducks. Poult Sci. (2018) 97:321829. doi: $10.3382 / \mathrm{ps} /$ pey162

33. Chen Y, Xie Y, Zhong R, Han H, Liu L, Chen L, et al. Effects of graded levels of xylo-oligosaccharides on growth performance, serum parameters, intestinal morphology, and intestinal barrier function in weaned piglets. J Anim Sci. (2021) 99:skab183. doi: 10.1093/jas/sk ab183

34. Zhao X, Yang J, Ju Z, Wu J, Wang L, Lin H, et al. Clostridium butyricum ameliorates salmonella enteritis induced inflammation by enhancing and improving immunity of the intestinal epithelial barrier at the intestinal mucosal level. Front Microbiol. (2020) 11:299. doi: 10.3389/fmicb.2020. 00299

35. Xiao F, Yu J, Guo Y, Deng J, Li K, Du Y, et al. Effects of individual branchedchain amino acids deprivation on insulin sensitivity and glucose metabolism in mice. Metabolism. (2014) 63:841-50. doi: 10.1016/j.metabol.2014. 03.006

36. Kim MJ, Parvin R, Mushtaq MM, Hwangbo J, Kim JH, Na JC, et al. Influence of monochromatic light on quality traits, nutritional, fatty acid, and amino acid profiles of broiler chicken meat. Poult Sci. (2013) 92:2844-52. doi: 10.3382/ps.201303159

37. Zhang D, Zhu C, Fang Z, Zhang H, Yang J, Tao K, et al. Remodeling gut microbiota by Clostridium butyricum (C. butyricum) attenuates intestinal injury in burned mice. Burns. (2020) 46:1373-80. doi: 10.1016/j.burns.2020. 01.007 
38. Yu C, Liu S, Chen L, Shen J, Niu Y, Wang T, et al., Effect of exercise and butyrate supplementation on microbiota composition and lipid metabolism. $J$ Endocrinol. (2019) 243:125-35. doi: 10.1530/JOE-19-0122

Conflict of Interest: The authors declare that the research was conducted in the absence of any commercial or financial relationships that could be construed as a potential conflict of interest.

Publisher's Note: All claims expressed in this article are solely those of the authors and do not necessarily represent those of their affiliated organizations, or those of the publisher, the editors and the reviewers. Any product that may be evaluated in this article, or claim that may be made by its manufacturer, is not guaranteed or endorsed by the publisher.

Copyright (c) $2021 \mathrm{Cai}, \mathrm{Hu}$, Tang, Jiang, Geng, Huang and Kong. This is an open-access article distributed under the terms of the Creative Commons Attribution License (CC BY). The use, distribution or reproduction in other forums is permitted, provided the original author(s) and the copyright owner(s) are credited and that the original publication in this journal is cited, in accordance with accepted academic practice. No use, distribution or reproduction is permitted which does not comply with these terms. 